\title{
Revisiting Relationship Marketing in Emerging Markets: The Case of Turkish Exportes
}

\author{
İrem Eren-Erdoğmuş* \\ Marmara University
}

\author{
A. Müge Yalçın** \\ Marmara University
}

\author{
Aichurek Bopieva*** \\ International Atatürk Alatoo University
}

\begin{abstract}
Astract
The purpose of this study is to explore relationship marketing in international B2B markets, with a specific focus on the impact of communication, cultural sensitivity, and shared values on relational exchange elements of commitment, trust, and export performance. The context of the study is chosen as Turkey since the number of studies on international relationship marketing in emerging market contexts needs to be increased. The model is tested upon 214 export market cases using structural equations modeling, and the findings confirm the relationships among the variables when the exporters originated from Turkey. The findings show that relationship marketing is a driver of business success and highlight the importance of cultural sensitivity as a significant driver of communication, trust, and commitment. The results imply that distributors should be sensitive to ways of doing business in Turkey and create common frames of reference with the Turkish exporters to inspire communication, trust, and commitment, all directly related to the market performance.
\end{abstract}

Keywords: relationship marketing, international marketing, emerging markets, trust, commitment, cultural sensitivity, shared values, communication.

\section{Yükselen Pazarlarda İlişkisel Pazarlamayı Değerlendirme: Türk İhracat Firmaları Vakası}

\section{Özet}

$\mathrm{Bu}$ çalışmanın amacı uluslararası örgütsel pazarlama açısından ilişkisel pazarlama konusunu ele almaktır. Bu amaç doğrultusunda örgütler arasındaki iletişim, kültürel duyarlılık, ortak değerler hususlarının güven ve bağlılık üzerine ve bağlılı̆̆ın da ihracat performansı üzerine etkisi araştırılmıştır. Yükselen pazarlarda uluslararası ilişkisel pazarlama çalışmalarının artırılması gerektiği görüşüne dayanarak, araştırma önemli bir yükselen pazar olan Türkiye' de kurgulanmıştır. Oluşturulan model 114 Türk firmasının ihracat gerçekleştirdiği 214 pazar için yapısal eşitlik modeli kullanılarak test edilmiştir. Sonuçlar, daha önceki çalışmaların bulgularını destekler çıkmıştır; ilişkisel

İrem Eren-Erdoğmuş is an Associate Professor in the Department of Management at Marmara University, Anadolu Hisarı Campus, Anadolu Hisarı, 34810, Istanbul, Turkey. E-mail: ireme@marmara.edu.tr

** A. Müge Yalçın is an Associate Professor in the Department of Management at Marmara University, Anadolu Hisarı Campus, Anadolu Hisar1, 34810, Istanbul, Turkey. E-mail: myalcin@marmara.edu.tr

**** Aichurek Bopieva is a lecturer in the Department of Management at International Atatürk Alatoo University, Bishkek, Kyrgyzstan. E-mail: aychurok@yahoo.com 
pazarlama ihracat performansını etkiler çıkmıştır. Çalışma özellikle kültürel duyarlılığın iletişim, güven ve bağlllık üzerindeki olumlu etkisini ortaya koymuştur. Elde edilen bulgular, Türk ihracat firmaları ile çalışan distribütörlerin iyi ilişkiler geliştirmek ve pazar başarısına ulaşmak için, iş yaparken Türk kültürüne duyarlı davranmaları, Türk ihracat firmaları ile aynı dili konuşmak için ortak değerlere önem vermeleri gerektiği sonucunu vurgulamaktadır.

Anahtar kelimeler: ilişkisel pazarlama, uluslararası pazarlama, yükselen pazarlar, güven, bağlılık, kültürel duyarlılık, ortak değerler, iletişim.

$\mathrm{T}$

The changing dynamics of the marketplace such as technological developments, globalization, quality orientation, and competitive pressures necessitated a transformation in marketing from transaction to relationship orientation in the late 20th Century. This orientation puts an emphasis on customer satisfaction, trust, commitment, retention and places the long term, profitable buyer-seller relationship at the focus of a firm's strategy formulation in order to achieve competitive advantage, greater efficiency, superior financial performance, and reduced risks (Achrol, 1991; Hunt, Arnett, and Madhavaram, 2006; Kalwani and Narayandas, 1995; Morgan and Hunt, 1994). Relationship marketing became a topic of importance in both domestic and international markets. As more firms started to partake in international marketing to gain profits outside their home country, it became important for firms to explore ways of conducting successful international business and marketing; thus the scope of relationship marketing extended to the international arena.

Internationalization coupled with severe competition pressured companies to establish long-term relationships with their international business partners, and to work in an environment of harmony, collaboration, and mutual understanding in order achieve profitability, productivity, and sales growth in the target markets. The research stream in international relationship marketing provides insights into the development of relationships among different international partners like distributors, suppliers, dealers, importing/exporting managers, and even the firm's key executives. The studies question the degree to which cultural differences, trust, communication, bonding, commitment, reciprocity, empathy, satisfaction, shared values, and power impact buyer-seller relations (e.g., Kumar et al., 1995; Chadee and Zhang, 2000; Pressey and Selassie, 2002; Huang et al., 2003; Nes et al., 2007; Doney et al., 2007; Wasti and Wasti, 2008; Lohtia et al., 2009; Katsikeas et al., 2009). Furthermore, most of these studies have examined the performance in the international context, specifically in the export performance.

Exporting is one of the popular research topics in international marketing literature (e.g., Leonidou and Kaleka, 1998; Leonidou et al., 2002; Çavuşgil et al., 2004; Styles et al., 2008; Styles and Ambler, 1994, 2000). As more companies are attempting to conduct business and marketing in the international arena, exporting and export management are gaining more importance. Export management is defined by Leonidou et al. (2002) as the process of managing relationships with foreign customers and parties operating inside or outside the company's supply chain. In an export market, a balanced portfo- 
lio of relationships is an important goal (Leonidou and Kaleka, 1998). Thus, drawing the key concepts from the seminal work of Morgan and Hunt (1994), the aims of this study are to explore long-term relationship building in export B2B markets and to link commitment between the parties to performance.

The main premise of the model is that commitment is a key factor in export market performance (Morgan and Hunt, 1994; Lohtia et al., 2005; Nes et al., 2007; Styles and Amber, 2000), and trust is essential in fostering it (Morgan and and Hunt, 1994; Garbarino and Johnson, 1999). The study also explores the sequential relationships between relational constructs such as cultural sensitivity, communication, shared values and trust, and commitment. Communication is treated as a central element in this respect since collaborative communication plays a central role in the formation of trust, and cooperation and enhances the continuity of a relationship (Morgan and Hunt, 1994; Anderson and Narus, 1990; Kumar, 1995; Nes et al., 2007). Shared values and cultural sensitivity are also believed to have a positive influence on communication, trust, and commitment in international markets. A structural equations modeling is employed to achieve this end.

The context of the study is chosen as Turkey since the number of studies on international relationship marketing in emerging market contexts still needs to be increased (Flambard-Ruaud, 2005; Wasti and Wasti, 2008). The emerging markets are characterized as relationship rich in essence (Styles et al., 2008); therefore it is interesting to assess which relational factors in particular lead to successful relationship building and export market performance in return. An understanding of the concept of international relationship marketing and commitment-trust theory on export market performance from the perspective of emerging markets is timely and will further enhance the coverage of the extant literature. Turkey is one of the dynamic emerging markets (The World Bank, 2009) and is an export-oriented country with growing exports. In the years between 1996 and 2006, Turkey's export has increased substantially and it is still increasing despite the global financial crisis that has shaken the world in 2008-2009. In 1996, the total export of Turkey was 23 billion US dollars; in 2006 the total export equaled 85 billion US dollars, and in 2010 the total exports reached 129 billion US dollars (Türkiye İhracatçılar Meclisi/Turkish Exporters' Assembly, 2011). The country is described as a high "power distance, feminine culture" (Hofstede, 1980), where collectivist acting, intimate relationships, and informal communication are valued; (Kabasakal and Bodur, 2002: 46). Turkey serves as a good base to test the exporter-distributor relationship propositions from an emerging market context, which is believed to be a significant contribution of this study.

\section{Theoratical Background and Hypotheses}

Among the factors that influence relationship marketing-based strategy success are relational factors such as trust, commitment, cooperation, keeping promises, shared values and communication (Hunt et al., 2006; Samiee and Walters, 2003; Leonidou et al., 2006). These variables are given equal importance in both domestic and interna- 
tional relationship marketing (Arora, 2008), and are considered critical in international buyer-seller relationships (Brencic et al., 2008; Rosson and Ford, 1982; Samiee and Walters, 2003; Styles and Ambler, 2000). A theoretical model shown in Figure 1 was developed using the relational factors of cultural sensitivity, shared values, communication, trust and commitment.

Figure 1

Theoretical Model

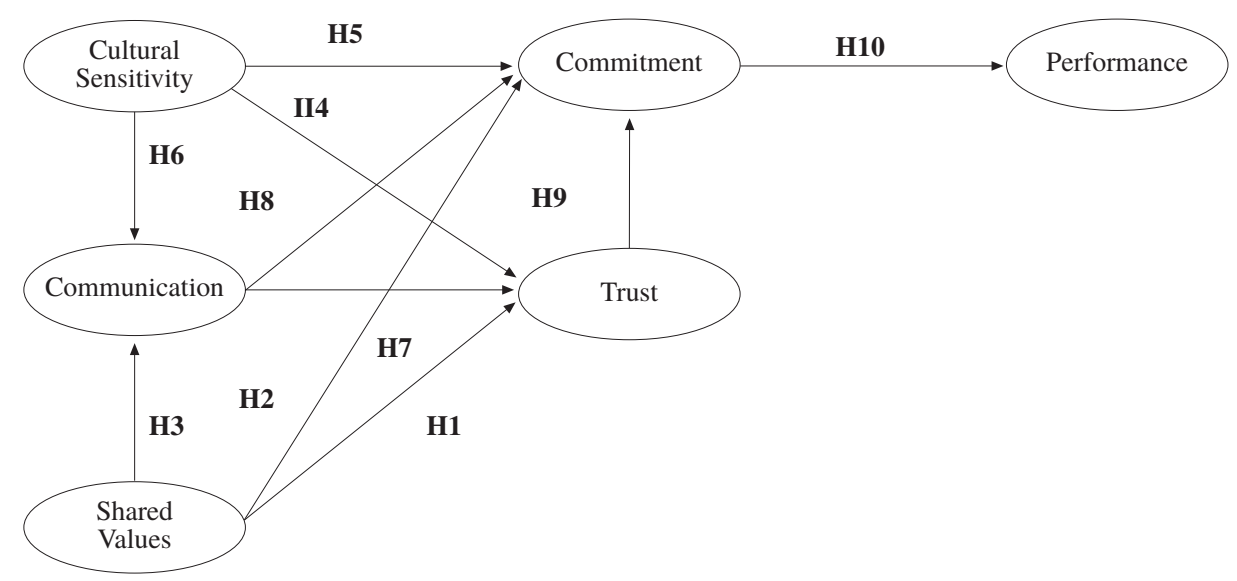

\section{Impact of Shared Values on Trust, Commitment, and Communication}

Shared values are defined by Morgan and Hunt (1994: 25) as "the extent to which partners have beliefs in common about what behaviors, goals, and policies are important or unimportant, appropriate or inappropriate and right or wrong." Shared values are considered an important component in building relationships (Evans and Laskin, 1994), being a direct antecedent of relationship commitment and trust (Morgan and Hunt, 1994; Peppers and Rogers, 2004). According to the authors, the ability to develop trust in a relationship is influenced by the parties' shared beliefs concerning appropriate behaviors, goals, and policies. It is also believed that when exchange partners share values, their ties increase and they become more committed to the relationship (Morgan and Hunt, 1994; Sin et al., 2005). Thus:

H 1: The greater the level of shared values between an exporter and a distributor, the greater will be the exporter's trust in the distributor.

$\boldsymbol{H}$ 2: The greater the level of shared values between an exporter and a distributor, the greater will be the exporter's commitment to the distributor.

Shared values act as a common frame of reference from which to initiate effective communication as well. When parties share common values, conduct, and policies, they feel close to each other, share a platform of commonness, are more open and inclined to continue communication (Sarbaugh, 1988). Thus: 
H 3: The greater the level of shared values between an exporter and a distributor, the greater will be the communication between them.

\section{Impact of Cultural Sensitivity on Trust, Commitment, and Communication}

LaBahn and Harich (1997: 31) define cultural sensitivity as “a firm's understanding of and adaptation to its exchange partner's domestic business practices as perceived by its partner." Other definitions of cultural sensitivity also stress awareness of differences between domestic and foreign business practices, understanding, addressing, managing and adapting to the exchange partner's domestic business practices (Toyne and Walters, 1989: 187; Skarmeas et al., 2002: 763).

Lohtia et al. (2009), Styles et al. (2008), Nguyen et al. (2004), and Voss et al. (2006) in their studies argue that one partner's trust in the other will grow as one of the partners becomes more culturally sensitive; this is due to the belief that when one of the partners is culturally sensitive, this partner is willing to adapt to differences in a socially appropriate way and have beliefs of goodwill and good intentions. Furthermore, when partners appreciate different practices, are accustomed to local market conditions and adjust accordingly, the result is enhanced commitment (Skarmeas et al., 2002; Styles et al., 2008). Thus:

$\boldsymbol{H}$ 4: The greater the level of cultural sensitivity of the distributor to the exporter's business practice, the greater will be the exporter's trust in the distributor.

$\boldsymbol{H}$ 5: The greater the level of cultural sensitivity of the distributor to the exporter's business practice, the greater will be the exporter's commitment to the distributor.

Studies also suggest that sensitivity to a partner's culture leads to better communication, increasing frequency and openness in a relationship. Cultural sensitivity and communication have a positive relationship (Kale and Barnes, 1992; LaBahn and Harich, 1997). Thus:

$\boldsymbol{H}$ 6: The greater the level of cultural sensitivity of the distributor to the exporter's business practice, the greater will be the communication between them.

\section{Impact of Communication on Trust and Commitment}

In business to business relationship marketing literature, the importance of information exchange or communication is highlighted (Duncan and Moriarty, 1998; Herbst, 1999; Sin et al., 2005; Sahadev, 2008). Communication is defined by Anderson and Narus (1984: 66) broadly as "the formal as well as informal sharing of meaningful and timely information between firms." It is a two-way process that includes listening, transparency, and frequent sharing of information (Anderson and Weitz, 1989; 1992; Anderson and Narus, 1990; MacMillan, Money, Money, and Downing, 2005; Mohr, Fisher and Nevin, 1996). Trust can emerge in an environment of frequent, rich, open, honest, reciprocal communication (Anderson and Narus, 1990; Morgan and Hunt, 1994; Dyer and Chu, 2000; Fawcett, Magnan, and Williams, 2004; Sahadev, 2008; Doney, 
Barry, and Abratt, 2007). Moreover, communication fosters confidence in the continuity of the relationship, creates an atmosphere of mutual support, reduces conflict, and increases commitment (Anderson and Narus, 1990; Anderson and Weitz, 1989; Dwyer, Schurr and Oh, 1987). Thus:

$\boldsymbol{H}$ 7: The greater the level of communication between an exporter and a distributor, the greater will be the exporter's trust in the distributor.

$\boldsymbol{H}$ 8: The greater the level of communication between an exporter and a distributor, the greater will be the exporter's commitment to the distributor.

\section{Impact of Trust on Commitment}

Trust has a great significance in relationship marketing as an essential ingredient for a successful relationship (Berry, 2002; Doney and Cannon, 1997; Doney, Cannon and Mullen, 1998; Garbarino and Johnson, 1999; Selnes, 1998; Sirdeshmukh, Singh, and Sabol, 2002). Trust is defined by Schurr and Ozanne (1985: 940) as "the belief that a party's word or promise is reliable and a party will fulfill his/her obligations in an exchange relationship." Research shows that relationship marketing is built on the foundation of trust (Berry, 1995; Morgan and Hunt, 1994). It creates safety, credibility, and security (Selnes, 1998) and allows buyers and sellers to work together in a collaborative fashion, overcoming conflicts, and a building on each other's strengths (Morgan and Hunt, 1994).

Trust is directly linked to commitment, being one of its major determinants and finds support in literature (Morgan and Hunt, 1994; Garbarino and Johnson, 1999; Kingshott and Pecotich, 2007; Leonidou et al., 2006; Doney et al., 2007; Styles et al., 2008; Geyskens et al., 1999; Gounaris, 2005; Moorman et al., 1992; Tellefsen and Thomas, 2005). These studies suggest that the more trust one partner has in the other partner, the more affectively and calculatively committed the partner will be to the other. Thus:

$\boldsymbol{H}$ 9: The greater the level of trust of an exporter in a distributor, the greater will be the exporter's commitment to the distributor.

\section{Impact of Commitment on Export Market Performance}

Most of the researchers propose that commitment is central to relationship marketing (Dwyer et al., 1987; Gundlach, Achrol, and Mentzer, 1995; Morgan and Hunt, 1994; Selnes, 1998; Sheth and Parvatiyar, 2002). Commitment is defined as "an implicit or explicit pledge of relational continuity between exchange partners" (Dwyer et al., 1987: 19). It represents the highest stage of relational bonding, and willingness of partners to make short-term sacrifices in order to realize longer-term benefits (Dwyer et al., 1987; Anderson and Weitz, 1992; Moorman et al., 1992; Morgan and Hunt, 1994). Research (Aaby and Slater, 1989; Nes et al., 2007; Lohtia et al., 2005; Styles and Ambler, 2000; Skarmeas et al., 2002; Styles et al., 2008; Çavuşgil and Zou, 1994) shows that commitment is actually positively related to export market performance, which is defined according to Çavuşgil and Zou (1994: 4) as “the extent to which a firm's objectives, 
both economic and strategic, with respect to exporting a product into a foreign market, are achieved through planning and execution of export marketing strategy." Thus:

$\boldsymbol{H}$ 10: The greater the level of the exporter's commitment to the distributor, the greater will be the export market performance.

\section{Research Design and Methodology}

\section{Data Collection and Sampling}

Data collection was carried through the administration of structured questionnaires with eligible managers in charge of international operations of Turkish export firms. The exporter-distributor relationship was taken as the unit of analysis. The interviewees were asked to fill out the same questionnaire for both a successful market and also for an unsuccessful market. The criteria for being successful and unsuccessful was based on the perception of the interviewees of their performance in each market in terms of sales, growth, and strategic position. The original English version of the questionnaire was first translated into Turkish. The variables and scales were then pre-tested through a series of in-depth face-to-face interviews with three export managers. Based on their opinions and feedback, the Turkish version of the questionnaire was revised and finalized. Finally, the questionnaire was translated back into English to make sure that the questions coincided with the original English version.

The sampling frame was drawn from the directory located under the Turkish Exporters' Assembly webpage on the Internet. Each year the Turkish Exporters' Assembly (www.tim.org.tr) carries out a study to identify the first 1000 export companies in Turkey and announces the results. The sampling frame used in this research was the whole directory of 1000 exporter companies announced by the Turkish Exporters' Assembly for 2008. Depending on the size of the company, the owners, general managers and export managers were used as key informants for each company. Several researchers (Brouthers, O’Donnell and Hadjimarcou, 2005; Brouthers and Xu, 2002; Hoskisson, Eden, Lau and Wright, 2000) have stressed the difficulties related to collecting primary data in emerging markets such as the managers' suspicion about the motives of the researchers and the intended purposes of the study, lack of perceived benefits, as well as (over)emphasis on confidentiality which ultimately result in relatively low response rates. These authors suggest that on-site data collection might be the best method to overcome these difficulties. Accordingly, it was decided to conduct face-to-face interviews with the managers, and all the firms located outside of Istanbul were eliminated since it was hard to reach and convince them. This left a sample frame of 438 export companies which were contacted by phone and/or e-mail and were interviewed on-site upon agreement. In total, 214 questionnaires (114 successful and 100 unsuccessful export market cases) were collected and analyzed. 
Table 1

Comparative Exploratory and Confirmatory Factors Analysis Results for Shared Values, Communication, Cultural Sensitivity, Commitment, and Trust

\begin{tabular}{|c|c|c|c|c|}
\hline Items* & EFA Factor Loadings & CFA Factor Loadings & $t$ value & \\
\hline \multicolumn{5}{|c|}{ Factor 1: Cultural Sensitivity $(\alpha=0,9374 ; \mathrm{VE}=19,248(\%) ; \mathbf{C R}=0,9405 ; \mathrm{AVExtr}=0,6382)$} \\
\hline C.SENST1 & ,644 &, 755 & $\mathrm{a}$ & \\
\hline C.SENST2 &, 690 &, 858 & 13,341 & $* * *$ \\
\hline C.SENST3 &, 554 &, 895 & 11,203 & $* * *$ \\
\hline C.SENST4 &, 732 &, 789 & 12,576 & $* * *$ \\
\hline C.SENST5 &, 788 &, 818 & 12,877 & $* * *$ \\
\hline C.SENST6 &, 735 &, 829 & 12,777 & $* * *$ \\
\hline C.SENST7 &, 822 &, 748 & 10,358 & $* * *$ \\
\hline C.SENST8 &, 726 &, 752 & 11,580 & $* * *$ \\
\hline C.SENST9 &, 594 &, 730 & 9,834 & $* * *$ \\
\hline
\end{tabular}

Factor 2: Shared Values $(\alpha=0,9068 ;$ VE $=12,395(\%)$; CR = 0,9007; AVExtr $=0,6944)$

\begin{tabular}{l|l|l|l|l} 
S.VALUE1 &, 769 &, 773 & $\mathrm{a}$ & \\
S.VALUE2 &, 772 &, 881 & 16,645 & $* * *$ \\
S.VALUE3 &, 670 &, 814 & 11,437 & $* * *$ \\
S.VALUE4 &, 732 &, 861 & 11,865 & $* * *$
\end{tabular}

Factor 3: Commitment $(\alpha=0,8491 ; \mathrm{VE}=11,674(\%)$; CR = 0,8413; $\operatorname{AVExtr}=0,4359)$

\begin{tabular}{l|l|l|l} 
COMMIT1 &, 468 &, 689 & a \\
COMMIT2 &, 497 &, 661 & 10,103 \\
COMMIT3 &, 511 &, 723 & 9,380 \\
COMMIT4 &, 611 &, 757 & 9,831 \\
COMMIT5 &, 719 &, 711 & 8,215 \\
COMMIT6 &, 614 &, 554 & 7,255 \\
COMMIT7 &, 590 &, 481 & 6,481
\end{tabular}

Factor 4: Trust $(\alpha=0,8923 ; \operatorname{VE}=9,879(\%)$; CR = 0,8825; $\operatorname{AVExtr}=0,5745)$

\begin{tabular}{|c|c|c|c|c|}
\hline & & & & \\
\hline TRUST3 &, 520 & 870 & a & \\
\hline TRUST1 &, 547 &, 873 & 14,237 & $* * *$ \\
\hline TRUST2 &, 592 &, 921 & 17,003 & $* * *$ \\
\hline TRUST4 &, 561 &, 810 & 15,630 & $* * *$ \\
\hline TRUST5R &, 763 &, 369 & 4,994 & $* * *$ \\
\hline TRUST6R &, 735 &, 536 & 8,432 & $* * *$ \\
\hline Factor 5: Co & Inicat & $=9,21$ & VExtr = & \\
\hline COMMUN1 &, 516 &, 751 & a & \\
\hline COMMUN2 &, 704 &, 831 & 11,221 & $* * *$ \\
\hline COMMUN3 & ,913 &, 746 & 8,525 & $* * *$ \\
\hline COMMUN4 & ,682 & ,754 & 8,231 & $* * *$ \\
\hline
\end{tabular}

Goodness-of-fit indices: $\chi^{2}(d f)=320,385(297) ; P=0,168 ; \chi^{2} / d f=1,079 ; G F I=0,917 ; A G F I=0,869 ;$ RMSEA = 0,019; $R M S R=0,044$

Note: $\alpha=$ Cronbach Reliability test; $V E=$ Variance Explained; $a=$ in CFA this regression weight is fixed at 1,000; $* * *$ $p<0,001 ; C R=$ Construct Reliability; VExtr $=$ Variance Extracted $(>0.50)$

*The items and scales are given in Appendix. 


\section{Measures}

Relational Factor Measures: All measurement items and their assessments are provided in Table 1. Also provided in Table 1 are the factor loadings of the items, obtained from exploratory (principal axis factoring with varimax rotation) and confirmatory factor analysis of five constructs, namely, shared values, communication, cultural sensitivity, commitment and trust.

The measure of shared values was adapted from Sin et al. (2005) consisting of 4 items that indicated whether the company shares the same worldview, same opinions, same feelings and same values with its international partner. The measure of cultural sensitivity was adapted from LaBahn and Harich (1997) and some of the items were developed by the researchers. Four items that were derived from LaBahn and Harich (1997) measured exporters' perception of distributors' understanding of, adaptation to, sensitivity to, and awareness of domestic business practices. In addition, five items were developed by the researchers based on the work of Albaum and Duerr (2008) and these items measured the awareness of the business negotiation style, culture, business practices, awareness of how to conduct communication with Turkish people, and willingness to keep up with business culture and other environmental factors in Turkey. In total, nine items were used to measure the cultural sensitivity. The measure of communication consisted of four items and they were adapted from the studies of LaBahn and Harich (1997) and Nes et al. (2007). The items adapted measured two-way communication, formal and informal information sent and received between the firms.

The measure of trust was adapted from Morgan and Hunt (1994) and Leonidou et al. (2002). The measure consisted of six items that measured the reliability, integrity, and trustworthiness. The measure of relationship commitment consisted of seven items that were adapted from Morgan and Hunt (1994) and Skarmeas et al. (2002); four items from Morgan and Hunt (1994) measured importance of commitment and its significance, attachment to, and maximum effort to maintain it. The other three items from Skarmeas et al. (2002) measured behavioral commitment that described the efforts of the exporter toward relationship preservation.

These five constructs were measured on a five-point Likert scale using the end terms of "strongly agree" and "strongly disagree" for each statement. The Cronbach alphas ranged from 0.8491 to 0.9427 , and thus, the constructs were reliable and internally consistent. Following exploratory factor analysis, confirmatory factor methods were used in an exploratory fashion, as has been suggested by Larry (1989) as a follow-up procedure to exploratory factor identification, assessing the validity of the measures. All loadings of the confirmatory factor analysis for shared values, communication, cultural sensitivity, commitment and trust were significant $(\mathrm{p}<0.05)$, providing evidence of convergent validity. All loadings were greater than 0.4 ; only one loading was close to 0.4 , indicating marginal acceptance level. All the factor loadings were considered fair to excellent. To test for discriminant validity, Fornell and Larcker's (1981) procedure was followed. In all cases, the squared correlation between two constructs was less than the average variance extracted estimates of the two constructs, providing evidence of discriminant validity. For instance, the average variance extracted of trust $(0,57)$ is 
greater than the square of its correlations with commitment $(0.363)$, with communications (0.291) and other measures.

The Confirmatory Factor Analysis Model for shared values, communication, cultural sensitivity, commitment and trust fit well when compared to the guidelines from Hair, Black, Babin, and Anderson (2009), with $\chi^{2}=320.385$ (degrees of freedom =297). Additional indices also fit with the recommended requirements (Hair et al., 2009; Bentler and Chou, 1987; Hu and Bentler, 1999): the goodness-of-fit index (GFI) has a value of 0,917, indicating good fit; adjusted goodness-of-fit (AGFI) value of 0,869 is close to the recommended level of .90, indicating marginal acceptance level. The value of RMSEA is equal to 0,019 , indicating good fit; the RMSR value of 0,044 also indicates good fit.

Export Performance Measures: Export market performance had been a popular topic in many researches and was measured in different ways (Bilkey, 1982; Çavuşgil, 1984; Çavuşgil and Zou, 1994; Cooper and Kleinschmidt, 1985; Piercy, Katsikeas, and Cravens, 1997; Rosson and Ford, 1982). In this paper, the measure of export market performance consisted of 4 items, and the most frequently used performance measures that appeared to be economic in nature were considered. These measures were export sales, profits from exports, export intensity and management's perceived success (Çavuşgil and Zou, 1994; Nes et al., 2007). The performance construct was measured on a five-point Likert scale using the end terms of "very low" and "very high" for each statement. The exploratory and confirmatory factor analysis for this construct was conducted separately from the rest of the scales. The overall results of the exploratory factor analysis proved that all the constructs were uni-dimensional. The factor loadings for performance ranged from 0,831 to 0,959 and all were significant, indicating a considerably practical significance, with an explained variance of $71 \%$. The model fit for performance construct was encouraging with a chi square value of 1,381 ( $\mathrm{df}=$ 2). Other indices of fit were GFI =0,997; AGFI =0,984; RMSEA =0,000; RMSR = 0,008. GFI and AGFI values indicated acceptable fit, again compared to the guidelines. The RMSR value of 0,008 also indicated acceptable fit and the RMSEA value of 0,000 indicated that the model fit reasonably well. In summary, these results provided evidence that the measurements were highly satisfactory.

A separate exploratory factor analysis was also employed to assess the potential problems caused by common method variance, using the procedure recommended by Podsakoff and Organ (1986). The results including all the variables used in the questionnaire indicated that the first factor did not account for a majority of the variance in any construct, and there was no general factor in the unrotated factor structure. The correlation matrix of all the dependent and independent variables is presented in Table 2.

\section{Research Findings}

The structural equations modeling method, which allows the simultaneous modeling of several related regression relationships, was used to assess the model. Before the structural analysis was conducted, the items under each construct were aggregated to form a single factor based on the factor analyses results. The path coefficients were 
tested for significance; looking at the results given in Figure 2, it can be said that all the paths were significant at the 0.05 levels, indicating a significant relationship between the two specific variables linked by a path in the model.

Table 2

\section{Correlations}

\begin{tabular}{|c|c|c|c|c|c|c|c|}
\hline & & S.VALUES & COMMITMT & TRUST & COMMUNIC & PERFORMC & CULTSENS \\
\hline \multirow[t]{2}{*}{ S.VALUES } & $\begin{array}{l}\text { Pearson } \\
\text { Correlation }\end{array}$ & 1 &, $560(* *)$ &, $535(* *)$ &, $495(* *)$ &, $544(* *)$ &, $611(* *)$ \\
\hline & Sig. (2-tailed) & . &, 000 &, 000 &, 000 &, 000 &, 000 \\
\hline \multirow[t]{2}{*}{ СОМмIтMT } & $\begin{array}{l}\text { Pearson } \\
\text { Correlation }\end{array}$ & & 1 &, $603(* *)$ &, $512(* *)$ &, $582(* *)$ &, $592(* *)$ \\
\hline & Sig. (2-tailed) & & . &, 000 &, 000 &, 000 &, 000 \\
\hline \multirow[t]{2}{*}{ TRUST } & $\begin{array}{l}\text { Pearson } \\
\text { Correlation }\end{array}$ & & & 1 &, $463(* *)$ &, $500(* *)$ &, $586(* *)$ \\
\hline & Sig. (2-tailed) & & & . &, 000 &, 000 &, 000 \\
\hline \multirow[t]{2}{*}{ COMMUNIC } & $\begin{array}{l}\text { Pearson } \\
\text { Correlation }\end{array}$ & & & & 1 &, $506(* *)$ &, $546(* *)$ \\
\hline & Sig. (2-tailed) & & & & . &, 000 &, 000 \\
\hline \multirow[t]{2}{*}{ PERFORMC } & $\begin{array}{l}\text { Pearson } \\
\text { Correlation }\end{array}$ & & & & & 1 &, $548(* *)$ \\
\hline & Sig. (2-tailed) & & & & & . &, 000 \\
\hline \multirow[t]{2}{*}{ CULTSENS } & $\begin{array}{l}\text { Pearson } \\
\text { Correlation }\end{array}$ & & & & & & 1 \\
\hline & Sig. (2-tailed) & & & & & & . \\
\hline
\end{tabular}

** Correlation is significant at the 0.01 level (2-tailed).

$N=214$

Figure 2

\section{Path Analysis Model}

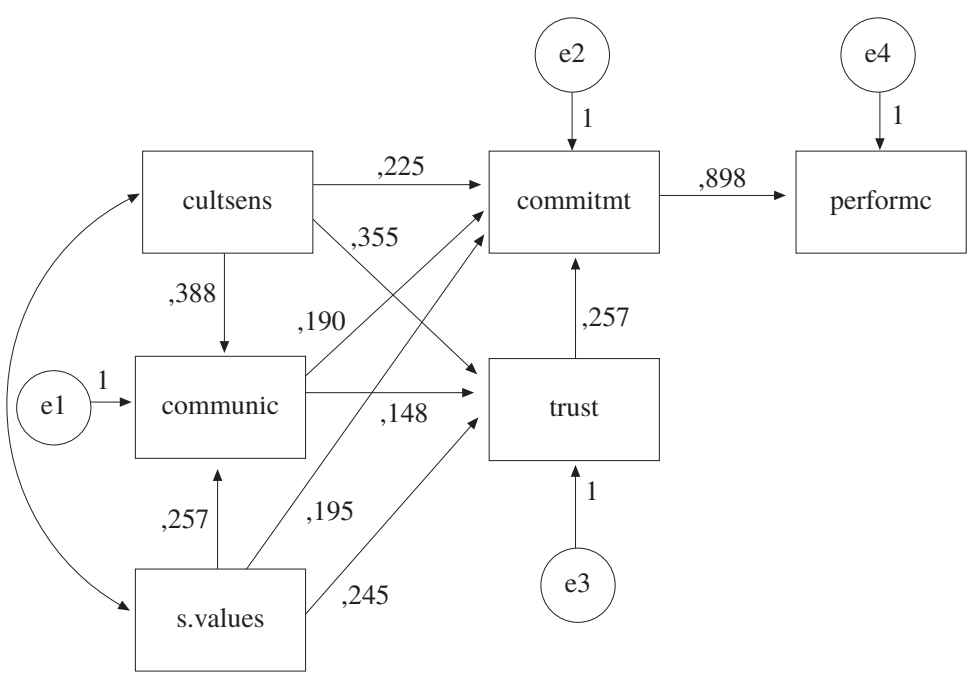


Overall, the model fit well, with $\chi^{2}=2,432$, degrees of freedom $=6$ and $\mathrm{p}$ with significance level of 0,296, indicating acceptable fit. Additional indices also fit recommended requirements: the goodness-of-fit index (GFI) had a value of 0,996, indicating acceptable fit; adjusted goodness-of-fit (AGFI) value of 0,960, also indicated acceptance level. The value of RMSEA was equal to 0,032, indicating close approximate fit; the RMSR value of 0,011 again indicated acceptable fit. In summary, the goodness-of-fit was adequate to assume the appropriateness of the model. Thus, the results supported all of the hypotheses presented in the research. The results were interpreted as follows. Both cultural sensitivity (coefficient: $0.388, \mathrm{p}<0.05$ ) and shared values (coefficient: 0.257 , $\mathrm{p}<0.05$ ) exerted a positive influence on communication. Nearly $34 \%$ of the variance in communication was explained by these two variables $\left(\mathrm{R}^{2}=0.339\right)$. However, interpreting the coefficients, the impact of cultural sensitivity was greater than the impact of shared values on communication. Communication (coefficient: $0.148, \mathrm{p}<0.05$ ), along with cultural sensitivity (coefficient: $0.355, \mathrm{p}<0.05$ ) and shared values (coefficient: 0.245 , $\mathrm{p}<0.05)$ influenced trust positively with an explained variance of $40.8 \%\left(\mathrm{R}^{2}=0.408\right)$. Again the impact of cultural sensitivity on trust, this time, was greater than the other variables. Despite its significance, the effect of communication was the least influential in the formation of trust compared to the other constructs. Looking at the influencers of commitment, it was seen that all four variables, communication (coefficient: 0.190, $\mathrm{p}<0.05$ ), cultural sensitivity (coefficient: $0.225, \mathrm{p}<0.05$ ), shared values (coefficient: $0.195, \mathrm{p}<0.05$ ), and trust (coefficient: $0.257, \mathrm{p}<0.05$ ) influenced the commitment of the exporter positively. Nearly half of the variance in commitment was explained by these variables $\left(\mathrm{R}^{2}=0.495\right)$. Finally, commitment (coefficient: $0.898, \mathrm{p}<0.05$ ) was found to influence export performance positively, explaining $23 \%$ of the variance in the variable $\left(\mathrm{R}^{2}=0.238\right)$. Discussion and implications of the findings are discussed in the next section.

\section{Discussion and Conclusions}

Healthy, lasting and prospering export business relationships do not happen accidentally; instead they require supportive and coordinated relational parameters that need to be taken into account by export company managers and foreign trading partners. Our study supports the fact that this does not change whether the country of origin of a firm is a developed market or not. The importance of relationship marketing is evident in emerging market contexts as well. This is an important finding in that it shows that relationship marketing is one universal area that every company from both advanced and emerging nations should pay attention to as a way to improve international business success. Thus to secure the trust and commitment of the emerging market exporter, distributors should be culturally sensitive, enhance shared values, build good communication, and establish trust. Commitment, in return, boosts export market performance which is important for the success and prosperity of both firms.

Even though all relational variables found significant support, the importance of cultural sensitivity as a significant driver of communication, trust, and commitment out performed the others in this study. The implication might be that cultural sensitiv- 
ity is one significant area that deserves special attention of distributors doing business with firms from emerging markets. These nations have been striving to find their place among the developed nations for a very long time. Up to now, they have had to adapt to or import the practices and business styles of the developed nations, as the followers. Therefore, it might be of value to them if their trading partners recognized their culture, showed respect, and adapted to it when doing business with them. Cultural sensitivity may make it easier for the firms from emerging markets to trust and bond emotionally to their partners. Hence, it is suggested that distributors should understand how to conduct business with firms from emerging markets; they must be willing to adapt their ways of doing business, and know the business style, culture and practices of these nations. Turkey is characterized as a collectivist culture (Hofstede 1980), where the nonverbal behavior, environment, and situation matters in communication and negotiations; therefore, managers should invest in learning the culture, the nonverbal behavior and acting before they meet their Turkish export partners. Cultural training and language skill development, combined with effective senior-level visits, might be a solution to enhancing cultural understanding, and adaptation.

Similarly, shared values also prove influential in the communication process, and in trust and commitment formation though its impact is lower when compared to cultural sensitivity. All people and companies have values; however, most of the time, it is difficult to perceive what these values are. Nevertheless, distributors should find out the common values they hold with the exporters and form a common frame of reference for communication, thus gaining the confidence and loyalty of their emerging market partners. As discussed before, emerging market firms might be responsive to the idea that they share the same feelings and world view with their trade partners, and in feeling understood, be more open to interaction and relationship.

Communication is also an important factor that positively affects trust and commitment. Therefore, exporters and distributors should develop and work on improving communication in order to achieve trust and commitment. Today, technological developments have simplified information exchange and further accelerated it (Flambard-Ruaud, 2005; Kim, Çavuşgil, and Calantone, 2006; Myers and Cheung, 2008). The Internet and computer networks are increasingly affordable, providing an easy and fast access to sharing needed information and increasing the quality and quantity of information. The firms using the Internet, B2B portals and online live messengers are able to communicate with business partners on a real time daily basis. Firms should invest in the latest communication tools without forgetting the traditional method of face-to-face communication by conducting field visits to improve their communication.

Even though the role of communication in our model is significant, its impact is relatively low when compared to cultural sensitivity and shared values. This might be because of the fact that Turkish organizational structure is more like a pyramid, and each member of the society accepts authority. There is little communication and directives are accepted without questioning formal communication structures in such a society (Sargut, 2001). Therefore, communication alone may not have enough impact on relationship building or the formation of trust and commitment of the Turkish export firms. The 
Muslim, Sunni sect part of the populated Turkish population (Kabasakal and Bodur, 2002) believes that the Islamic community is a brotherhood, and warm relationships, feelings of security, and a family-like environment are important. Sensitivity to culture and shared values between parties may be more likely to create such an environment, and would enhance trust and commitment to the trade partners in return.

In this study, trust is also proposed as an essential factor for relationship marketing as an antecedent to commitment. The impact of developing trust in exporter-distributor relationship is essential for the quality of the relationships. International markets have different cultural mechanisms; they carry business risk partially because of the fact that it is harder to obtain full information about the environment and key actors. Therefore, trusting a business partner and being committed to this partner is very important for exporters. Eastern cultures are described as "relationship rich" in the sense that it is hard to break up a relationship once it is formed. Trust is very crucial in these nations; people trust the individuals that they do business with and then they trust the firm and the brand (Styles et al., 2008). Therefore, distributors should work on minimizing or removing "distrust" and should work on creating an environment characterized by trust. However, this may require some time since the partners have to know each other well enough to feel safe in dealing with each other. Once trust turns into commitment, success is more likely to come, as suggested by the literature (Terawatanavong and Quazi, 2006).

\section{Limitations and Recommendations for Further Research}

This research paper has provided relevant and interesting results for understanding relationship marketing in the international marketing context; however, it is important to identify some of its limitations. The data in this study was obtained from the export companies located in Istanbul, Turkey. Therefore, the representativeness of the sample is not excellent, even though through face-to-face in-depth interview technique, a good number of respondents are included in the research, given that the context is an emerging market. Moreover, this study focuses specifically on the relationships between Turkish exporters and their chosen foreign distributors. As a result, the relationships were considered from one point of view, that of the exporters. Essentially, considering both parties of the relationship would help toward understanding objectively the both parties' perception of the relationship. Finally, in relationship marketing there are many other relational factors that could affect relationships in the international context. For instance, factors like bonding, empathy, reciprocity, power, cooperation, conflict and competence also exist. Theoretical models using these and other relational factors should be built and researched in order to enhance the existing knowledge in the future as well.

\section{References}

Aaby, N.E. and Slater, S.F. (1989). "Management Influences on Export Performance: A Review of the Empirical Literature 1978-88," International Marketing Review, 6(4): 7-26.

Achrol, R.S. (1991). "Evolution of the Marketing Organization: New Forms for Turbulent Environments," Journal of Marketing, 55(October): 77-93. 
Albaum, G. and Duerr, E. (2008), International Marketing and Export Management (6 $6^{\text {th }}$ edition). Harlow, England: Prentice Hall/Financial Times.

Anderson, E. and Weitz, B. (1989). "Determinants of Continuity in Conventional Industrial Channel Dyads," Marketing Science, 8(4): 310-323.

-----, (1992). "The Use of Pledges to Build and Sustain Commitment in Distribution Channels," Journal of Marketing Research, 29(Febuary): 18-34.

Anderson, J.C. and Narus, J.A. (1984). "A Model of the Distributor's Perspective of DistributorManufacturer Working Relationships," Journal of Marketing, 48(Fall): 62-74.

------, (1990). “A Model of Distributor Firm and Manufacturer Firm Working Partnerships," Journal of Marketing, 54(January): 42 -58.

Arora, H. (2008). "International Business and Relationship Marketing: A Conceptual Study," The Icfai Journal of International Business, 3(1): 46-58.

Bentler, P.M. and Chou, C. (1987). "Practical Issues in Structural Modeling," Sociological Method and Research, 16(1): 78-117.

Berry, L.L. (1995). "Relationship Marketing of Services - Growing Interest, Emerging Perspectives," Journal of the Academy of Marketing Science, 23(4): 236-245.

-----, (2002). "Relationship Marketing of Services - Perspectives from 1983 and 2000," Journal of Relationship Marketing, 1(1): 59-77.

Bilkey, W.J. (1982). "Variables Associated with Export Profitability," Journal of International Business Studies, 13(2): 39-55.

Brencic, M., Ekar, A., and Virant, V. (2008). "The Influence of Relationship Marketing Components on Export Performance: A Comparison of Transitional vs. Established Markets," Nase Gospodarstvo (Our Economy), st. 5-6, Original Scientific Paper: 9-18.

Brouthers, L.E., O’Donnell, E., and Hadjimarcou, J. (2005). “Generic Product Strategies for Emerging Market Exports into Triad Nation Markets: A Mimetic Isomorphism Approach," Journal of Management Studies, 42(1): 225-245.

Brouthers, L.E. and Xu, K. (2002). "Product Stereotypes, Strategy, and Performance Satisfaction: The Case of Chinese Exporters," Journal of International Business Studies, 33 (4): 57-67.

Çavuşgil, S.T. (1984). "Organizational Characteristics Associated with Export Activity,” Journal of Management Studies, 21(1): 3-22.

Çavuşgil, S.T., Deligönül, S., and Zhang, C. (2004). "Curbing Foreign Distributor Opportunism: An Examination of Trust, Contracts, and the Legal Environment in International Channel Relationships," Journal of International Marketing, 12(2): 7-27.

Çavuşgil, S.T. and Zou, S. (1994). "Marketing Strategy-Performance Relationship: An Investigation of the Empirical Link in Export Market Ventures," Journal of Marketing, 58(1): 1-21.

Chadee, D.D. and Zhang, B.Y. (2000). "The Impact of Guanxi on Export Performance: A Study of New Zealand Firms Exporting to China," Journal of Global Marketing, 14(1Ğ2): 129 -149.

Cooper, R.G. and Kleinschmidt, E.J. (1985). "The Impact of Export Strategy on Export Sales Performance," Journal of International Business Studies, 16(1): 37-55.

Doney, P.M. and Cannon, J.P. (1997). "An Examination of the Nature of Trust in Buyer-Seller Relationships,” Journal of Marketing, 61(April): 35-51. 
Doney, P., Barry, J.M., and Abratt, R. (2007). "Trust Determinants and Outcomes in Global B2B Services," European Journal of Marketing, 41(9/10): 1096-1116.

Doney, P.M., Cannon, J.P., and Mullen, M.R. (1998). "Understanding the Influence of National Culture on the Development of Trust," Academy of Management Review, 23(3): 601 -620.

Duncan, T. and Moriarty, S.E. (1998). "A Communication-Based Marketing Model for Managing Relationships," Journal of Marketing, 62(April): 1-13.

Dwyer, F.R., Schurr, P.H., and Oh, S. (1987). "Developing Buyer-Seller Relationships," Journal of Marketing, 51(April): 11-27.

Dyer, J.H. and Chu, W. (2000). "The Determinants of Trust in Supplier-Automaker Relationships in the US, Japan, and Korea," Journal of International Business Studies, 31(2): 259-285.

Evans, J.R. and Laskin, R.L. (1994). "The Relationship Marketing Process: A Conceptualization and Application,” Industrial Marketing Management, 23(5): 439-452.

Fawcett, S.E., Magnan, G.M., and Williams, A.J. (2004). "Supply Chain Trust Is Within Your Grasp," Supply Chain Management Review, 8(2): 20-26.

Flambard-Ruaud, S. (2005). "Relationship Marketing in Emerging Economies," Vikalpa: Journal of Decision Makers, 30(3): 53-63.

Fornell, C. and Larcker D.F. (1981). "Evaluating Structural Equation Models with Unobservable Variables and Measurement Error," Journal of Marketing Research, 18(1): 39-50.

Garbarino, E. and Johnson, M.S. (1999). "The Different Roles of Satisfaction, Trust, and Commitment in Customer Relationships," Journal of Marketing, 63(April): 70-87.

Geyskens, I., Steenkamp, E.M., and Kumar, N. (1999). “A Meta-Analysis of Satisfaction in Marketing Channel Relationships," Journal of Marketing Research, 36(2): 223-238.

Gounaris, S.P. (2005). "Trust and Commitment Influences on Customer Retention: Insights from Business-to-Business Services," Journal of Business Research, 58(2): 126-140.

Griffith, D.A., Çavuşgil, S.T.. and Xu, S. (2008). "Emerging Themes in International Business Research," Journal of International Business Studies, 39(7): 1220-1235.

Grönroos, C. (1994). "From Marketing Mix to Relationship Marketing: Towards a Paradigm Shift in Marketing," Management Decision, 32(2): 4-20.

Gundlach, G.T., Achrol, R.S., and Mentzer, J.T. (1995). “The Structure of Commitment in Exchange," Journal of Marketing, 59(January): 78-92.

Hair, J.F., Black, W.C., Babin, B.J., and Anderson, R.E. (2009). Multivariate Data Analysis (7 $7^{\text {th }}$ edition). Upper Saddle River, N.J.: Prentice Hall.

Herbst, F.J. (1999). “The Influence of Communication on an Effective Relationship Marketing Strategy for Sport Unions in the New Millennium," Communicare, 18(2): 53-80.

Hofstede, G. (1980). Culture's Consequences. CA: Sage Publications.

Hoskisson, R.E., Eden, L., Lau, C.M., and Wright, M. (2000). "Strategy in Emerging Economies," Academy of Management Journal, 43: 249-267.

Hu, L. and Bentler, P.M. (1999). "Cutoff Criteria for Fit Indexes in Covariance Structure Analysis: Conventional Criteria versus New Alternatives," Structural Equation Modeling, 6 (1): 1-55. 
Huang, Y., Rayner, C., and Zhuang, L. (2003). "Does Intercultural Competence Matter in Intercultural Business Relationship Development?," International Journal of Logistics: Research and Applications, 6(4): 277-288.

Hunt, S.D., Arnett, D.B., and Madhavaram, S. (2006). "The Explanatory Foundations of Relationship Marketing Theory," Journal of Business and Industrial Marketing, 21(2): 72-87.

Kabasakal, H. and Bodur, M. (2002). “Arabic cluster: a Bridge between East and West,” Journal of World Business, 37: 40-54.

Kale, S.H. and Barnes, J.W. (1992). "Understanding the Domain of Cross-National Buyer-Seller Interactions," Journal of International Business Studies, 23(1): 101-132.

Kalwani, M.U. and Narayandas, N. (1995). "Long-Term Manufacturer-Supplier Relationships: Do They Pay Off for Supplier Firms?," Journal of Marketing, 59(January): 1-16.

Katsikeas, C.S., Skarmeas, D., and Bello, D.C. (2009). "Developing Successful Trust-Based International Exchange Relationships,” Journal of International Business Studies, 40: 132-155.

Kim, D., Çavuşgil, S.T., and Calantone, R.J. (2005). "The Role of Information Technology in Supply Chain Relationships: Does Partner Criticality Matter?," Journal of Business and Industrial Marketing, 20(4/5): 169-178.

Kingshott, P.J. and Pecotich, A. (2007). "The Impact of Psychological Contracts on Trust and Commitment in Supplier-Distributor Relationships," European Journal of Marketing, 41(9/10): 1053-1072.

Kumar, N., Scheer, L.K., and Steenkamp, J.E.M. (1995). "The Effects of Supplier Fairness on Vulnerable Resellers," Journal of Marketing Research, 32(February): 54-65.

LaBahn, D.W. and Harich, K.R. (1997). "Sensitivity to National Business Culture: Effects on U.S.Mexican Channel Relationship Performance," Journal of International Marketing, 5 (4): 29-51.

Larry, G.D. (1989). "Comparison of Exploratory and Confirmatory Factor Analysis," Little Rock: The Annual Meeting of the Mid-South Educational Research Association, 37.

Leonidou, L.C. and Kaleka, A.A. (1998). "Behavioral Aspects of International Buyer Seller Relationships: Their Association with Export Involvement," International Marketing Review, 15(5): 373-397.

Leonidou, L.C., Katsikeas, C.S., and Hadjimarcou, J. (2002). "Building Successful Export Business Relationships: A Behavioral Perspective,” Journal of International Marketing, 10 (3): 96-115.

Leonidou, L.C., Palihawadana, D., and Theodosiou, M. (2006). "An Integrated Model of the Behavioral Dimensions of Industrial Buyer-Seller Relationships," European Journal of Marketing, 40(1/2): 145-173.

Lohtia, R., Bello, D.C., Yamada, T., and Gilliland, D.I. (2005). "The Role of Commitment in ForeignJapanese Relationships: Mediating Performance for Foreign Sellers in Japan," Journal of Business Research, 58: 1009-1018.

Lohtia, R., Bello, D.C., and Porter, C.E. (2009). "Building Trust in US-Japanese Business Relationships: Mediating Role of Cultural Sensitivity," Industrial Marketing Management, 38: 239-252.

MacMillan, K., Money, K., Money, A., and Downing, S. (2005). "Relationship Marketing in the Not-for-Profit Sector: An Extension and Application of the Commitment-trust Theory," Journal of Business Research, 58: 806-818.

Mohr, J.J., Fisher, R.J. and Nevin, J.R. (1996). "Collaborative Communication in Interfirm Relationships: Moderating Effects of Integration and Control,” Journal of Marketing, 60 (July): 103-115. 
Moorman, C., Zaltman, G., and Deshpande, R. (1992). "Relationships between Providers and Users of Market Research: The Dynamics of Trust within and between Organizations," Journal of Marketing Research, 29(August): 314-28.

Morgan, R.M. and Hunt, S.D. (1994). "The Commitment-Trust Theory of Relationship Marketing," Journal of Marketing, 58(July): 20-38.

Myers, M.B. and Cheung, M. (2008). "Sharing Global Supply Chain Knowledge," MIT Sloan Management Review, 49(4): 67-73.

Nes, E.B., Solberg, C.A., and Silkoset, R. (2007). "The Impact of National Culture and Communication on Exporter-Distributor Relations and on Export Performance," International Business Review, 16, $405-424$.

Nguyen T.T.M., Barrett, N.J., and Nguyen, T.D. (2004). "Cultural Sensitivity, Information Exchange, and Relationship Quality: The Case of Vietnamese Exporters and their Asian vs. European Importers," Journal of Customer Behavior, 3(3): 281-303.

Peppers, D. and Rogers, M. (2004). Managing Customer Relationships: A Strategic Framework. New Jersey: John Wiley and Sons, Hoboken.

Piercy, N.F., Katsikeas, C.S., and Cravens, D.W. (1997). "Examining the Role of Buyer-Seller Relationships in Export Performance," Journal of World Business, 31(1): 73-86.

Podsakoff, P.M. and Organ, D.W. (1986). "Self-Reports in Organizational Research: Problems and Prospects," Journal of Management, 12(4): 531-544.

Pressey, A.D. and Selassie, H.G. (2002). "Are Cultural Differences Overrated? Examining the İnfluence of National Culture on International Buyer-Seller Relationships," Journal of Consumer Behavior. 2(4): 354-368.

Rosson, P.J. and Ford, I.D. (1982). "Manufacturer-Overseas Distributor Relations and Export Performance," Journal of International Business Studies, 2: 59-81.

Sahadev, S. (2008). "Economic Satisfaction and Relationship Commitment in Channels," European Journal of Marketing, 42(1/2): 178-195.

Samiee, S. and Walters, P.G.P. (2003). "Relationship Marketing in an International Context: A Literature Review," International Business Review, 12: 193-214.

Sarbaugh, L. E. (1988). Intercultural Communication (Transaction edition). New Brunswick, NJ, USA: Transaction Books .

Schurr, P.H. and Ozanne, J.L. (1985). "Influences on Exchange Processes: Buyer's Preconceptions of a Seller's Trustworthiness and Bargaining Toughness," Journal of Consumer Research, 11(March): 939-953.

Selnes, F. (1998). "Antecedents and Consequences of Trust and Satisfaction in Buyer- Seller Relationships," European Journal of Marketing, 32(3/4): 305-322.

Sheth, J.N. and Parvatiyar, A. (2002). "Evolving Relationship Marketing into a Discipline," Journal of Relationship Marketing. 1(1): 3-16.

Sin, L.Y.M., Tse, A.C.B., Yau, O.H.M., Chow, R.P.M., Lee, J.S.Y., and Lau, L.B.Y. (2005). "Relationship Marketing Orientation: Scale Development and Cross-Cultural Validation," Journal of Business Research, 58: 185-194.

Sirdeshmukh, D., Singh, J., and Sabol, B. (2002). "Consumer Trust, Value, and Loyalty in Relational Exchanges," Journal of Marketing, 66(January): 15-37. 
Skarmeas, D., Katsikeas, C.S., and Schlegelmilch, B.B. (2002). "Drivers of Commitment and Its Impact on Performance in Cross-Cultural Buyer-Seller Relationships: The Importers Perspective," Journal of International Business Studies, 33(4): 757-783.

Styles, C. and Ambler, T. (1994). "Successful Export Practice: The UK Experience," International Marketing Review, 11(6): 23-47.

-----, (2000). “The Future of Relational Research in International Marketing: Constructs and Conduits,” International Marketing Review, 17(6): 492-508.

Styles, C., Patterson, P.G., and Ahmed, F. (2008). "A Relational Model of Export Performance," Journal of International Business Studies, 39: 880-900.

Tellefsen, T. and Thomas, G.P. (2005). "The Antecedents and Consequences of Organizational and Personal Commitment in Business Service Relationships," Industrial Marketing Management, 34 (1): 23-37.

Terawatanavong, C. and Quazi, A. (2006). "Conceptualizing the Link between National Cultural Dimensions and B2B Relationship," Asia Pacific Journal of Marketing and Logistics, 18(3): 173-183.

The World Bank, (2009), “Country Brief 2009,” Available [online] at: http://web.worldbank.org/ WBSITE/EXTERNAL/COUNTRIES/ECAEXT/TURKEYEXTN/0,,menuPK:361722 pagePK:141 132 piPK:141107 theSitePK:361712,00.html. (Accessed March 1, 2009).

Toyne, B. and Walters, P.G. (1989). Global Marketing Management: A Strategic Perspective. Massachusetts, USA: Allyn and Bacon.

Türkiye İhracatçllar Meclisi (Turkish Exporters’ Assembly). (2009). “İhracat Rakamları,” Available [online] at: http://www.tim.org.tr/index.php?option=com_content\&view=article\&id=625\&Itemid=135. (Accessed March 1, 2009).

Voss, K.E., Johnson, J.L., Cullen, J.B., Sakano, T., and Takenouchi, H. (2006). "Relational Exchange in US-Japanese Marketing Strategic Alliances," International Marketing Review, 23(6): 610-635.

Wasti, S.N. and Wasti, S.A. (2008). "Trust in Buyer-Supplier Relations: The Case of the Turkish Automobile Industry," Journal of International Business Studies, 39: 118-131. 


\section{Appendix}

Variables and Measurement Questions

\begin{tabular}{|c|c|c|c|}
\hline Variable & Scale Items & Source Scale & Source(s) and Year \\
\hline \multirow{7}{*}{$\begin{array}{l}\text { COMMIT- } \\
\text { MENT }\end{array}$} & COMMIT1 & $\begin{array}{l}\text { The relationship that my firm has with my } \\
\text { major distributor: ... is something we are } \\
\text { very committed to. }\end{array}$ & \multirow{4}{*}{$\begin{array}{l}\text { Morgan, Robert M. } \\
\text { and Shelby, D. Hunt } \\
\text { (1994). }\end{array}$} \\
\hline & COMMIT2 & $\begin{array}{l}\text { The relationship that my firm has with my } \\
\text { major distributor: ... is very important to my } \\
\text { firm. }\end{array}$ & \\
\hline & COMMIT3 & $\begin{array}{l}\text { The relationship that my firm has with my } \\
\text { major distributor: ...is something that my } \\
\text { firm intends to maintain indefinitely. }\end{array}$ & \\
\hline & COMMIT4 & $\begin{array}{l}\text { The relationship that my firm has with my } \\
\text { major distributor: ...deserves our firm's } \\
\text { maximum effort to maintain. }\end{array}$ & \\
\hline & COMMIT5 & $\begin{array}{l}\text { We devote more time to this distributor } \\
\text { when it needs help. }\end{array}$ & \multirow{3}{*}{$\begin{array}{l}\text { Skarmeas, Dionisis } \\
\text { and Constantine, S. } \\
\text { Katsikeas, Bodo B. } \\
\text { Schlegelmilch (2002). }\end{array}$} \\
\hline & COMMIT6 & $\begin{array}{l}\text { We adjust our marketing programs for this } \\
\text { distributor when necessary. }\end{array}$ & \\
\hline & COMMIT7 & $\begin{array}{l}\text { We provide special aid to this distributor } \\
\text { when it is in trouble. }\end{array}$ & \\
\hline \multirow{6}{*}{ TRUST } & TRUST1 & $\begin{array}{l}\text { In our relationship, my major distributor: ... } \\
\text { is perfectly honest and truthful. }\end{array}$ & \multirow{3}{*}{$\begin{array}{l}\text { Morgan, Robert M. } \\
\text { and Shelby, D. Hunt } \\
\text { (1994). }\end{array}$} \\
\hline & TRUST2 & $\begin{array}{l}\text { In our relationship, my major distributor: ... } \\
\text { can be trusted completely. }\end{array}$ & \\
\hline & TRUST3 & $\begin{array}{l}\text { In our relationship, my major distributor: ... } \\
\text { can be counted on to do what is right. }\end{array}$ & \\
\hline & TRUST4 & $\begin{array}{l}\text { Foreign customers have so far been very } \\
\text { frank in dealing with our company. }\end{array}$ & \multirow{3}{*}{$\begin{array}{l}\text { Leonidou, Leonidas } \\
\text { C. and Constantine, S. } \\
\text { Katsikeas, and John } \\
\text { Hadjimarcou (2002) }\end{array}$} \\
\hline & TRUST5R & $\begin{array}{l}\text { Several times foreign customers were caught } \\
\text { making false claims. (R). }\end{array}$ & \\
\hline & TRUST6R & $\begin{array}{l}\text { Foreign customers are engaged in behavior } \\
\text { characterized by deceit and fraud. (R). }\end{array}$ & \\
\hline \multirow{4}{*}{$\begin{array}{l}\text { SHARED } \\
\text { VALUES }\end{array}$} & S.VALUE1 & We share the same worldview. & \multirow{4}{*}{$\begin{array}{l}\text { Sin, Leo Y.M. and } \\
\text { Alan C.B. Tse, Oliver } \\
\text { H.M. Yau, Raymond } \\
\text { P.M. Chow, Jenny S.Y. } \\
\text { Lee, Lorett B.Y. Lau } \\
\text { (2005). }\end{array}$} \\
\hline & S.VALUE2 & $\begin{array}{l}\text { We share the same opinion about most } \\
\text { things. }\end{array}$ & \\
\hline & S.VALUE3 & $\begin{array}{l}\text { We share the same feelings toward things } \\
\text { around us. }\end{array}$ & \\
\hline & S.VALUE4 & We share the same values. & \\
\hline
\end{tabular}




\begin{tabular}{|c|c|c|c|}
\hline Variable & Scale Items & Source Scale & Source(s) and Year \\
\hline \multirow{9}{*}{$\begin{array}{l}\text { CULTURAL } \\
\text { SENSITIVITY }\end{array}$} & C.SENST1 & $\begin{array}{l}\text { This distributor understands how distribu- } \\
\text { tors and manufacturers conduct business in } \\
\text { Turkey. }\end{array}$ & \multirow{4}{*}{$\begin{array}{l}\text { LaBahn, Douglas W. } \\
\text { and Katrin R. Harich } \\
\text { (1997). }\end{array}$} \\
\hline & C.SENST2 & $\begin{array}{l}\text { This distributor is willing to adapt to Turk- } \\
\text { ish way of doing business. }\end{array}$ & \\
\hline & C.SENST3 & $\begin{array}{l}\text { This distributor is sensitive to the difficul- } \\
\text { ties we encounter when doing business in } \\
\text { Turkey. }\end{array}$ & \\
\hline & C.SENST4 & $\begin{array}{l}\text { This distributor is aware of how we conduct } \\
\text { business outside of Turkey. }\end{array}$ & \\
\hline & C.SENST5 & $\begin{array}{l}\text { This distributor is aware of how we conduct } \\
\text { negotiations in Turkey. }\end{array}$ & \multirow{5}{*}{$\begin{array}{l}\text { Developed by the au- } \\
\text { thor based on Albaum } \\
\text { and Duerr (2008). }\end{array}$} \\
\hline & C.SENST6 & $\begin{array}{l}\text { This distributor knows how to be for- } \\
\text { mally introduced to someone in business } \\
\text { negotiations. }\end{array}$ & \\
\hline & C.SENST7 & $\begin{array}{l}\text { This distributor is aware of business style, } \\
\text { culture and business practices in Turkey. }\end{array}$ & \\
\hline & C.SENST8 & $\begin{array}{l}\text { This distributor is aware of how to conduct } \\
\text { communication with Turkish people. }\end{array}$ & \\
\hline & C.SENST9 & $\begin{array}{l}\text { This distributor is willing to keep step with } \\
\text { the Turkish business culture and other envi- } \\
\text { ronmental factors in Turkey. }\end{array}$ & \\
\hline \multirow{4}{*}{$\begin{array}{l}\text { COMMUNI- } \\
\text { CATION }\end{array}$} & COMMUN1 & $\begin{array}{l}\text { Our company and this distributor maintain a } \\
\text { high level of two-way communication. }\end{array}$ & \multirow{2}{*}{$\begin{array}{l}\text { LaBahn, Douglas W. } \\
\text { and Katrin R. Harich } \\
\text { (1997). }\end{array}$} \\
\hline & COMMUN2 & $\begin{array}{l}\text { Our company and this distributor clearly } \\
\text { communicate our expectations to each other. }\end{array}$ & \\
\hline & COMMUN3 & $\begin{array}{l}\text { We have a well functioning formal system to } \\
\text { give information in this relationship. }\end{array}$ & \multirow{2}{*}{$\begin{array}{l}\text { Nes, E.B., C.A. Sol- } \\
\text { berg, and R. Silkoset, } \\
(2007) \text {. }\end{array}$} \\
\hline & COMMUN4 & $\begin{array}{l}\text { We have a well functioning informal system } \\
\text { to receive information in this relationship. }\end{array}$ & \\
\hline \multirow{4}{*}{$\begin{array}{l}\text { PERFOR- } \\
\text { MANCE }\end{array}$} & PERFORMC1 & $\begin{array}{l}\text { How is performance in this country in rela- } \\
\text { tion to the total company performance? }\end{array}$ & \multirow{3}{*}{$\begin{array}{l}\text { Nes, E.B., C. A. Sol- } \\
\text { berg, and R. Silkoset, } \\
(2007) \text {. }\end{array}$} \\
\hline & PERFORMC2 & $\begin{array}{l}\text { How are profits in this country in relation to } \\
\text { the total company profits? }\end{array}$ & \\
\hline & PERFORMC3 & $\begin{array}{l}\text { How are sales in this country in relation to } \\
\text { the total company sales? }\end{array}$ & \\
\hline & PERFORMC4 & $\begin{array}{l}\text { How is export intensity in this country in re- } \\
\text { lation to the total company export intensity? }\end{array}$ & $\begin{array}{l}\text { Developed by the } \\
\text { author based on } \\
\text { Çavuşgil and Zou } \\
\text { (1994). }\end{array}$ \\
\hline
\end{tabular}

